\title{
Aspiração folicular por via transvaginal guiada por ultra-som em eqüinos*
}

\author{
RAFAEL RODRIGUES \\ José Luiz Rodrigues (Orientador - UFRGS)
}

Banca: Rodrigo Costa Mattos (UFRGS), Cláudio Alves Pimentel (UFPel), Adriana Pires Neves (URCamp).

A técnica de aspiração folicular transvaginal guiada por ultra-som (TUGA) foi utilizada pela primeira vez em reprodução assistida de eqüinos em 1992 e desde então vem sendo aperfeiçoada. Com o crescente interesse nos procedimentos de transferência de oócitos (TO), transferência de gametas intrafallopiana (GIFT) e mais recentemente na transferência nuclear (TN), a recuperação de oócitos de boa qualidade tornou-se um passo fundamental do processo. Diversas técnicas e equipamentos podem ser empregados com esta finalidade. Os experimentos foram conduzidos com o objetivo de avaliar a taxa de recuperação de oócitos de folículos pré-ovulatórios de cinco protocolos de punções. Dois níveis de pressão negativa: Baixa (B) (150 - 200 $\mathrm{mmHg}$ ) e Alta (A) (250 - $300 \mathrm{mmHg}$ ) e três modelos de agulha: curta $14 \mathrm{G}(\mathrm{C} 14)$; curta $18 \mathrm{G}(\mathrm{C} 18)$ e longa 18 G (L18) foram testados. Cinquienta e quatro folículos de 48 éguas foram aspirados. Estes animais foram distribuídos completamente ao acaso em cinco grupos experimentais (G) GI: (B-C14) (n=22); GII: (B-L18) (n=3); GIII: (B-L18) (n=18); GIV: (A-C18) (n=5); GV: (AL18) $(\mathrm{n}=6)$. Vinte e duas éguas receberam $2500 \mathrm{UI}$ de hCG, 14 tiveram seus folículos aspirados e 2 oócitos foram recuperados (14,3\%) Dos 54 folículos aspirados, 4 oócitos foram recuperados (7,41\%): GI (n=1), GIII (n=1) e GIV (n=2). Três destes oócitos foram transferidos para o oviduto de éguas receptoras através das técnicas de GIFT (n=2) e TO (n=1). Não foi observado desenvolvimento embrionário nas receptoras nos 14, 15 e 16 dias pós-transferência.

Descritores: oócito, aspiração folicular, hCG, transferência de gametas. 


\title{
Equine transvaginal ultrasound-guided follicular aspiration ${ }^{* *}$
}

\author{
RAFAEL RODRIGUES
}

\author{
José Luiz Rodrigues (Adviser - UFRGS)
}

Committee: Rodrigo Costa Mattos (UFRGS), Cláudio Alves Pimentel (UFPel), Adriana Pires Neves (URCamp).

Follicular transvaginal ultrasound guided aspiration (TUGA) procedure was first used in equine assisted reproduction in 1992 an has been improved since then. With the increased interest in the techniques of oocyte transfer (OT) and gamete intrafallopian transfer (GIFT) and most recently in nuclear transfer (NT), the recovery of a good quality oocyte became an important step in the process. Different methods and equipments can be used with this purpose. The experiment was conducted with the objective to evaluate oocyte recovery rates from preovulatory follicles of five different punction protocols. Two levels of negative pressure: Low (L) (150-200 mmHg) and High (H) (250-300mmHg) and three needle types:short14G (S14); short $18 \mathrm{G}$ (S18) and long 18G (L18) were tested Fifty four follicles of 48 mares were aspired. This animals was randomicaly distributed in five experimental groups (G) GI: (L-S14) (n=22); GII: (L-L18) (n=3); GIII: (L-L18) (n=18); GIV: (H-S18) (n=5); GV: (H-L18) $(n=6)$.Twenty two mares received 2500UI of hCG, 14 mares had follicules aspired and 2 oocytes were recovered (14,3\%). Four oocytes were recovered from 54 follicular aspirations (7, 41\%): GI $(n=1)$, GIII $(n=1)$ and GIV (n=2). Three oocytes were transfered into the oviduct of recipient mares through GIFT $(n=2)$ and OT $(n=1)$. It was not observed embryonic development in recipient mares on days14, 15 and 16 after transfers.

Key words: oocyte, follicular aspiration, hCG, gametes transfer.

**Master's Thesis \# 435 (Field: Biotechnology of Reproduction) 51p. Graduated Program in Veterinary Sciences [www.ufrgs.br/ppgcv], Faculdade de Veterinária, Universidade Federal do Rio Grande do Sul ( UFRGS ), Porto Alegre, RS/Brazil. CORRESPONDENCE: R. Rodrigues [bomemodesto@bol.com.br]. 